\title{
Adrenal function evaluation in critically ill dogs with low doses of synthetic ACTH
}

\author{
Avaliação da função adrenal em cães portadores de doenças críticas com \\ baixa dose de ACTH sintético
}

Márcia Marques Jericó $^{1}$; Fernando Mathias Bento ${ }^{1}$ (D); Ricardo Duarte Silva ${ }^{2}$; Felipe Braz de Siqueira Cardozo ${ }^{3}$; Fabiano de Granville Ponce ${ }^{3}$; Rogério Márcio Soila ${ }^{4}$ Priscila Viau Furtado $;$ Fabrício Lorenzini Aranha Machado

\author{
${ }^{1}$ Universidade Anhembi Morumbi, São Paulo - SP, Brazil \\ ${ }^{2}$ All Care Vet, São Paulo - SP, Brazil \\ ${ }^{3}$ Hospital Veterinário Pompeia, São Paulo - SP, Brazil \\ ${ }^{4}$ Laboratório de Hormônios Provet, São Paulo - SP, Brazil
}

\begin{abstract}
The hypothalamus-pituitary-adrenal axis function may be impaired in patients with critical illnesses, especially cases of sepsis, named critical illness-related corticosteroid insufficiency (CIRCI). This study examined the function of the hypothalamic-pituitary-adrenal axis in normal dogs $(\mathrm{n}=10)$ and dogs with critical diseases $(\mathrm{n}=16)$, through determinations of endogenous ACTH (adrenocorticotropic hormone), basal cortisol and cortisol after stimulation in low doses of synthetic ACTH $(1.0 \mu \mathrm{g} / \mathrm{kg} / \mathrm{IV})$. The stimulation test with ACTH dose tested was verified as effective for evaluation of adrenal function in healthy and sick dogs. Ill dogs differed from healthy dogs by presenting higher basal cortisol values. Eight sick dogs presented a decrease in endogenous ACTH, basal cortisol, or $\Delta$-cortisol. No significant differences were found between the control groups and critically ill dogs for the values of endogenous ACTH, cortisol after stimulation or $\Delta$-cortisol. We concluded that the stimulation test with low-dose ACTH was effective for evaluation of adrenal function, as well as the fact that a considerable portion of critically ill dogs studied here, especially with sepsis, had evidence of inadequate corticosteroid response to stress.
\end{abstract}

Keywords: Canine. Glucocorticoid. Corticotropin. Sepsis. Critical diseases.

RESUMO

A função do eixo hipotálamo-hipófise-adrenal pode estar comprometida em pacientes com doenças críticas, em especial casos de sepse, sendo nomeada de Insuficiência Corticosteroide Relacionada à Doença Crítica (ICRDC). O presente trabalho analisou a função do eixo hipotálamo-hipófise-adrenal em cães normais $(n=10)$ e cães portadores de doenças críticas ( $\mathrm{n}=16$ ), por meio de determinações de ACTH (hormônio adrenocorticotrófico) endógeno, de cortisol basal e de cortisol após estímulo com baixa dose de ACTH sintético $(1,0 \mu \mathrm{g} / \mathrm{kg} / \mathrm{IV})$. Constatou-se que o teste de estimulação com ACTH na dose testada se mostrou eficaz para avaliação da função adrenal em cães sadios e doentes. Os cães doentes diferiram dos sadios ao apresentar valores maiores de cortisol basal. Oito cães doentes apresentaram diminuição do ACTH endógeno, do cortisol basal ou do $\Delta$-cortisol. Não foram encontradas diferenças significativas entre os grupos Controle e Criticamente enfermos para os valores de ACTH endógeno, cortisol após estimulação ou $\Delta$-cortisol. Concluiu-se que o teste de estimulação com baixa dose de ACTH mostrou-se eficaz para avaliação da função adrenal, assim como, uma parcela considerável da população de cães críticos aqui estudados, em especial com sepse, apresentaram evidências de resposta corticosteroide inadequada frente ao estresse.

Palavras-chave: Caninos. Glicocorticoides. Corticotrofina. Sepse. Doenças graves. 


\section{Correspondence to:}

Fernando Mathias Bento

Universidade Anhembi Morumbi

R. Jaceru, 247, Morumbi

CEP: 04705-000, São Paulo - SP, Brazil

e-mail: fembento@gmail.com

Received: March 02, 2020

Approved: June 01, 2020

How to cite: Jericó MM, Bento FM, Silva RD, Cardozo FBS, Ponce FG, Soila RM, Furtado PV, Machado FLA. Adrenal function evaluation in critically ill dogs with low doses of synthetic ACTH. Braz J Vet Res Anim Sci. 2020;57(2):e167299. https://doi.org/10.11606/issn.16784456.bjvras.2020.167299

\section{Introduction}

Critical illness, trauma and acute or extended periods of stress generate several responses of the body to meet its needs in order to survive. The hypothalamic-pituitary-adrenal (HPA) axis has a notable effect on the body's response to stress and maintenance of homeostasis during critical illness (Martin, 2011; Prittie et al., 2002). The response to stress is characterized by increased cortisol synthesis, as well as translocation of the cortisol-receptor complex to the cell nucleus. Glucocorticoids act by affecting the transcription of thousands of genes in all body cells and generating regulatory actions on metabolism, cardiovascular and immune systems in these situations (Marik et al., 2008).

The critical illness-related corticosteroid insufficiency (CIRCI) syndrome is characterized by inadequate production of cortisol during long periods of stress, especially in critical illnesses such as sepsis. The common clinical conditions related to this dysfunction are usually associated with a typical hemodynamic profile, characterized by high cardiac output, hypotension, and low vascular resistance. As this is not a classic picture of hypoadrenocorticism, this type of steroidal deprivation is relative and reversible and can have hypothalamic, pituitary or adrenal glands, as well as peripheral origin (American Association of Critical-Care Nurses, 2012; Arafah, 2006; Burkitt et al., 2007; Burkitt, 2015; Hamrahian et al., 2004; Martin, 2011; Peyton \& Burkitt, 2009; Salluh \& Fuks, 2006; Schoeman et al., 2007).

The HPA axis dysfunction in critically ill patients, i.e., those with actual or potentially fatal health problems, have been investigated in both human and veterinary medicine, although the results are still contradictory (American Association of Critical-Care Nurses, 2012; Burkitt et al., 2007; Martin, 2011; Schoeman et al., 2007). According to consensus of the American College of Critical Care Medicine (Marik et al., 2008), a diagnosis of CIRCI is established when critically ill patients show low levels of basal cortisol and poor response to ACTH stimulation, represented by $\Delta$-cortisol (delta cortisol). Values $<10 \mu \mathrm{g} / \mathrm{dL}$ for basal total cortisol or $<9 \mu \mathrm{g} / \mathrm{dL}$ for $\Delta$-cortisol are diagnostic for CIRCI in humans (Marik et al., 2008). Its prevalence rate is approximately 10 to $20 \%$ of critically ill patients and can increase up to $60 \%$ in patients with septic shock (Arafah, 2006; Marik et al., 2008).

In human medicine, the diagnosis and use of corticoid therapy for this type of steroid dysfunction, which is a partial one, is currently the object of interest, especially in cases of sepsis, trauma, burns, pancreatitis, and post-heart surgery. Adrenal insufficiency reports in patients with liver cirrhosis increase the mortality rate in association with critical illnesses, using the term hepato-adrenal syndrome. Studies indicate efficiency in using low corticosteroids doses in patients with those conditions, reducing the effects of septic shock, mortality, and length of stay in the intensive care unit (Arafah, 2006; Fede et al., 2012; Lian et al., 2019; Marik et al., 2008; Yao et al., 2019).

In veterinary medicine, the compiled studies that have been carried out thus far with critically ill dogs, admitted or not to intensive care units (ICU) have shown conflicting results. Prittie et al. (2002) studied 20 critically ill dogs, including animals with sepsis and diabetic ketoacidosis (DKA), evaluating adrenal function through endogenous ACTH, basal cortisol and after ACTH stimulation, observing no significant differences between the group of dogs that survived and those who died. Martin et al. (2008) studied 31 dogs with sepsis, gastric volvulus dilatation or severe trauma and did not observe any statistically significant alterations among the diseases regarding the measured parameters (endogenous ACTH, basal cortisol and after ACTH stimulation). From those, 55\% (17) obtained some alteration (cortisol after ACTH stimulation or endogenous ACTH below normal levels), suggestive of adrenal insufficiency and associated with increased need for vasopressors at low values of $\Delta$-cortisol.

Burkitt et al. (2007) studied 33 dogs with sepsis, of which $53 \%$ were discharged from the hospital. There was no correlation between survival and $\Delta$-cortisol levels. However, it was observed that dogs with $\Delta$-cortisol levels $<3 \mathrm{ug} / \mathrm{dL}$ had higher risk of developing hypotension and were four times more likely to die. Holford et al. (2008) evaluated 16 dogs with portosystemic shunt in the pre- and postoperative periods of ameroid ring constrictor placement, finding no significant differences in basal cortisol and post-ACTH 
levels in the control group, but just an increase in basal cortisol values in the post-surgical group.

In all the above mentioned studies, the dose of synthetic Cortrosyn $(\mathrm{ACTH})$ used to assess adrenal function ranged from $5 \mathrm{ug} / \mathrm{kg}$ body weight to $250 \mathrm{ug} / \mathrm{kg}$ per animal. A study developed by Martins \& Jericó (2017) compared the stimulation test with synthetic Cortrosyn at the conventional dose of $5 \mu \mathrm{g} / \mathrm{dL}$ and a low dose of $1 \mu \mathrm{g} / \mathrm{dL}$, using in their groups healthy dogs, dogs suspected of endogenous HAC, and dogs with endogenous HAC undergoing treatment with trilostane. As a result, authors obtained efficiency in the low-dose test in evaluating the HHA axis in all groups. Botsford et al. (2018) evaluated the efficacy of the low-dose synthetic ACTH test $1 \mu \mathrm{g} / \mathrm{dL}$ at the conventional dose of $5 \mu \mathrm{g} / \mathrm{dL}$ in dogs suspected of hypoadrenocorticism, finding equivalent values in both groups, reinforcing the test effectiveness diagnosis of this disease.

This study aims to evaluate adrenal function, based on the stimulation test with synthetic ACTH at low dose, in dogs that are carriers of critical illnesses represented by diabetic ketoacidosis, acute renal failure, pancreatitis and sepsis, on the first day of care. Furthermore, we aim to correlate the survival of these animals and the functional status of the hypothalamic-pituitary-adrenal axis.

\section{Materials and Methods}

Critically ill dogs, selected from the routine care at Anhembi Morumbi Veterinary Hospital and Pompeii Veterinary Hospital (São Paulo, SP, Brazil) were evaluated from August 2010 to June 2012. The category of critical illnesses included acute renal failure, cases of pancreatitis, sepsis, and diabetic ketoacidosis. The criteria for diagnosis of morbidities in animals included in the study were the data obtained from clinical history, physical examination, routine laboratory tests, endocrine function, blood gas analysis, abdominal ultrasonography, radiographies, and systolic blood pressure. The exclusion criterion established that the selected animals could not have undergone any previous medical-hospital intervention and, particularly, had not received any medication with glucocorticoids in the past $24 \mathrm{~h}$.

The control group was composed of healthy dogs that had not undergone any hospital intervention history, who also underwent adrenal function assessment.

Venous blood samples $(10 \mathrm{~mL})$ were collected for basal measurements of cortisol and plasma ACTH, as well as cortisol levels after stimulation with synthetic ACTH (tetracosactide, Synacthen ${ }^{\circ}$, Novartis) at a dose of $1.0 \mathrm{mg} / \mathrm{kg}$ intravenously with blood collection performed $1 \mathrm{~h}$ after drug administration.
Serum samples for basal and post-ACTH stimulation cortisol levels were placed in a dry tube and the samples for plasma ACTH measurement were placed in tubes with EDTA plus aprotinin protease inhibitor, according to recommendations made by Prittie et al. (2002). The calculation of $\Delta$-cortisol was made by subtracting the post-ACTH cortisol minus the basal cortisol value.

All material collection procedures were performed within the first $24 \mathrm{~h}$ after hospital admission and the immunochemiluminometric method (Immulite 2000 ACTH, Siemens, USA) was used to determine plasma levels of ACTH and radioimmunoassay (Cortisol Coat-a-Count, Siemens, USA) for cortisol measurements.

Serum samples for cortisol measurement were frozen, stored at $-20^{\circ} \mathrm{C}$ and subsequently performed at Hormone Laboratory of PROVET (São Paulo, Brazil). Due to the lability of endogenous ACTH, all blood samples were processed immediately in a refrigerated centrifuge at $5{ }^{\circ} \mathrm{C}$ for $5 \mathrm{~min}$ and stored in a freezer until measurements were performed by Laboratory of Hormones and Molecular Genetics (LIM-42) of Hospital das Clínicas of the University of São Paulo.

The values obtained at the adrenal function evaluation (baseline cortisol and post-ACTH, $\Delta$-cortisol, and plasma $\mathrm{ACTH}$ ) were correlated with clinical variables such as systemic blood pressure, electrolytes (sodium, potassium) and metabolic data (albumin, glucose, cholesterol, and triglycerides).

All results were expressed as medians, due to the non-parametric distribution of the obtained data. The differences between the two groups (control and critically ill) regarding the results of adrenal function were assessed using Mann-Whitney and Wilcoxon tests. Regression analysis was used to establish correlations between clinical variables and adrenal function (basal cortisol, post-stimulation, basal $\mathrm{ACTH}$, and $\Delta$-cortisol). The reference values were established based on the $5^{\text {th }}$ and $95^{\text {th }}$ percentiles of the control group. A p value $<0.05$ was considered statistically significant for all statistical analyses.

\section{Results}

Both in the group of healthy dogs as in the critically-ill group, the values of basal cortisol and $1 \mathrm{~h}$ after stimulation with synthetic ACTH at a dose of $1.0 \mu \mathrm{g} / \mathrm{kg} / \mathrm{IV}$ showed significant difference between them $(\mathrm{p}<0.05)$, as shown in Figure 1.

Control dogs: from 10 healthy animals selected, seven dogs were from Anhembi Morumbi Veterinary Hospital kennel, one dog belonged to donor group of Anhembi Morumbi Veterinary Hospital blood bank and two dogs belonged to 


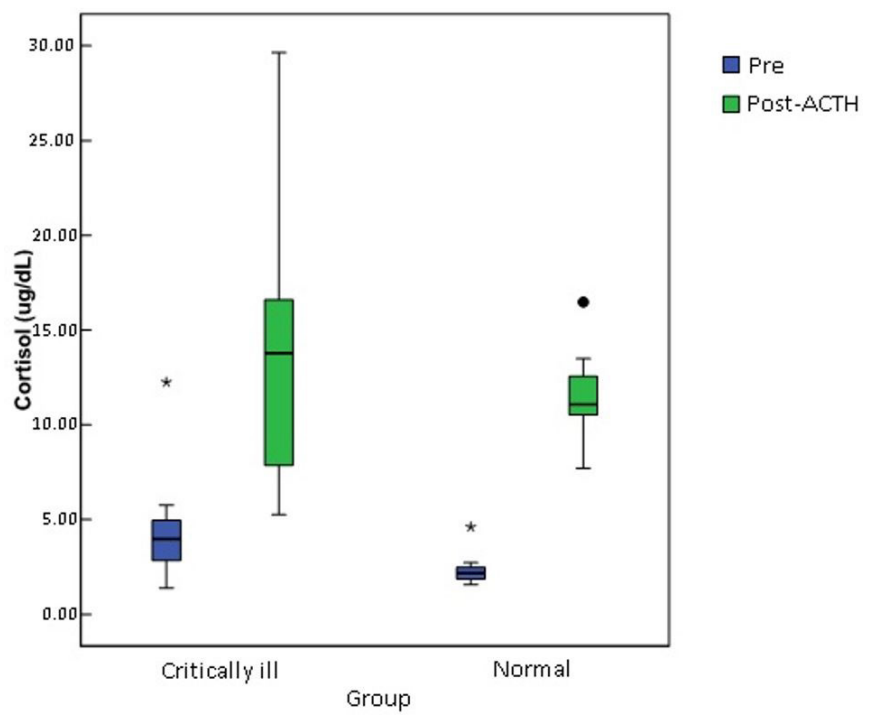

Figure 1 - Basal and post-ACTH cortisol levels in Critically ill $(\mathrm{n}=16)$ and Normal $(\mathrm{n}=10)$. The outlier value $(\bullet$ and $*)$

owners. As for the identification of these healthy animals, five were males, nine were mixed-breed, one was a Golden Retriever, aged between three and seven years with a body weight of 10 to $34 \mathrm{Kg}$. All dogs underwent routine tests such as whole blood count, renal function, liver function and blood glucose every six months, according to the rules of the kennel and the blood bank of Anhembi Morumbi Veterinary Hospital.

Critically ill dogs: 16 animals were selected, seven with pancreatitis, four with diabetic ketoacidosis (DKA), four with sepsis and one with acute kidney injury (AKI). There were four mixed-breed animals, three Yorkshires, two Shih Tzu, two Labradors, one Cocker, one Poodle, one Fox Terrier, one Dachshund and one Dalmatian. Thirteen of them were females and three were males, aged between 1 and 15 years, weighing between 2.55 and $40 \mathrm{~kg}$. The selected animals were initially submitted to the necessary examinations for diagnostic completion and subsequently underwent the tests proposed by this study.

Adrenal function: the results obtained for basal plasma ACTH in the group of healthy dogs $(n=10)$ showed a median of $13 \mathrm{pg} / \mathrm{mL}$, while the group of critically ill dogs $(\mathrm{n}=16)$ had a median of $16.5 \mathrm{pg} / \mathrm{mL}$, with no significant differences between the groups. Among the critically ill dogs, three had lower values (two sepsis and pancreatitis) and seven had higher values than those established for normal endogenous ACTH levels.

Regarding cortisol levels in the group of control dogs, the median basal cortisol value was $2.18 \mathrm{~g} / \mathrm{dL}$ and post-ACTH cortisol showed a median value of $11.1 \mathrm{ug} / \mathrm{dL}$, showing a significant increase between basal cortisol and post-ACTH cortisol values $(\mathrm{p}<0.005)$.

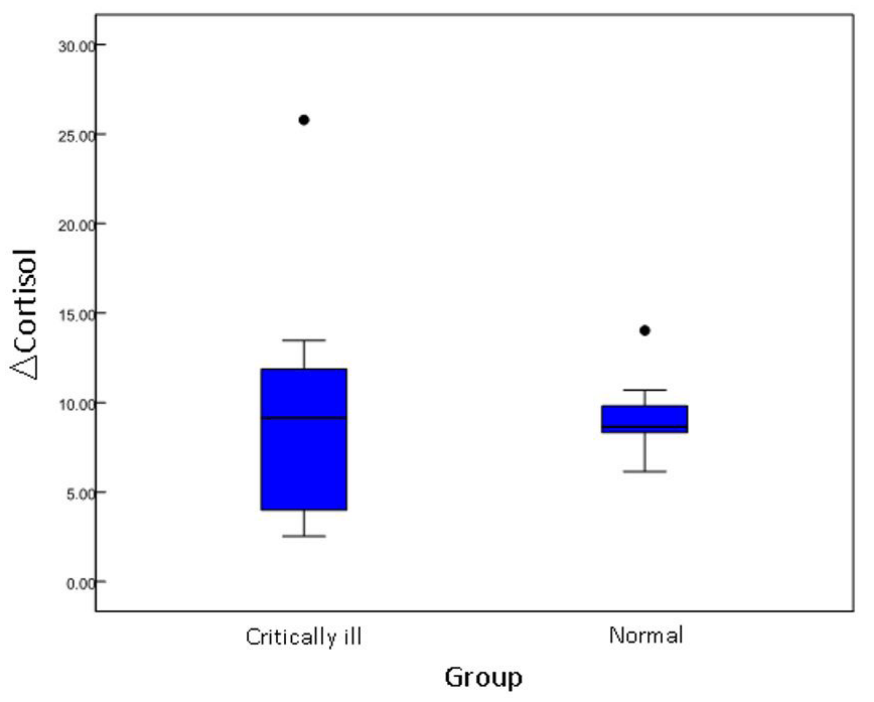

Figure 2 $-\Delta$-Cortisol values of Critically ill $(\mathrm{n}=16)$ and Normal $(\mathrm{n}=10)$. The outlier value $(\bullet)$

According to the results found in the control group, values ranging from 1.69 to $3.76 \mathrm{ug} / \mathrm{dL}$ for basal cortisol and from 8.16 to $15.13 \mathrm{ug} / \mathrm{dL}$ for post-ACTH cortisol ( $5^{\text {th }}$ and $95^{\text {th }}$ percentiles) were used as normal parameters for adrenal function assessment. From critically ill dogs, two presented basal cortisol levels below the normal range (sepsis and DKA) and nine dogs showed values above normal. Regarding post-ACTH cortisol levels, five dogs had values above and five below normal values. When comparing cortisol values between the groups, we observed that the group of critically ill dogs had significantly higher basal values than the normal animals $(\mathrm{p}<0.05$, Mann-Whitney test; Figure 2), whereas levels of cortisol after the ACTH stimulation test showed no significant differences between groups.

Regarding $\Delta$-cortisol, the values obtained in normal dogs showed a median of $8.65 \mathrm{ug} / \mathrm{dL}$. The normal values based on these results were 6.34 to $23.76 \mathrm{ug} / \mathrm{dL}$ ( $5^{\text {th }}$ and $95^{\text {th }}$ percentiles). Thus, comparing the $\Delta$-cortisol values of critically ill dogs to these results, six animals showed decreased $\Delta$ - cortisol (one pancreatitis, two DKA and three sepsis cases), showing a low response to stimulation test, but there was no significant difference between the critically ill and control groups ( $\mathrm{p}=0.897$, Mann-Whitney test). All results are shown in Table 1.

For clinical and laboratory variables, such as blood pressure, electrolytes (sodium and potassium) and metabolic levels (albumin, glucose, cholesterol, and triglycerides), there were no significant correlations with the values of adrenal function evaluation. However, from the group of critically ill dogs, nine had hypoalbuminemia.

From 16 critically ill dogs, four (25\%) died, two of which had diabetic ketoacidosis, one pancreatitis and the 
Table 1 - Endogenous ACTH, basal cortisol, post-ACTH cortisol and $\Delta$-cortisol levels in Control (n=10) and Critically ill Dogs $(n=16)$, São Paulo, SP, Brazil - 2020

\begin{tabular}{|c|c|c|c|c|}
\hline & $\begin{array}{c}\text { Basal } \\
\text { ACTH (pg/mL) }\end{array}$ & $\begin{array}{c}\text { Basal } \\
\text { Cortisol (ug/dL) }\end{array}$ & $\begin{array}{c}\text { Post-ACTH } \\
\text { Cortisol (ug/dL) }\end{array}$ & $\begin{array}{c}\Delta \text {-cortisol } \\
\text { (ug/dL) }\end{array}$ \\
\hline \multicolumn{5}{|c|}{ Control } \\
\hline Median & 13 & $2.18^{a . b}$ & $11.1^{\mathrm{a}}$ & 8.65 \\
\hline Minimum & 6 & 1.56 & 7.71 & 6.15 \\
\hline Maximum & 20 & 4.61 & 16.48 & 34.45 \\
\hline $5^{\text {th }}$ Percentile & 7.8 & 1.69 & 8.16 & 6.34 \\
\hline $95^{\text {th }}$ Percentile & 19.55 & 3.76 & 15.13 & 23.76 \\
\hline \multicolumn{5}{|c|}{ Critically ill } \\
\hline Median & 16.5 & $3.97^{a . b}$ & $13.78^{a}$ & 9.14 \\
\hline Minimum & 5 & 1.39 & 5.26 & 2.53 \\
\hline Maximum & 109 & 12.25 & 29.4 & 25.79 \\
\hline $5^{\text {th }}$ Percentile & 6 & 1.39 & 5.83 & 3.4 \\
\hline $95^{\text {th }}$ Percentile & 58.6 & 12.25 & 20.6 & 16.54 \\
\hline
\end{tabular}

other, sepsis. When comparing, among the critically ill dogs, animals that died $(\mathrm{n}=4)$ with those who survived $(\mathrm{n}=12)$, we observed that among the ones who died, two had lower $\Delta$-cortisol values than the normal standards established by the group. Moreover, the group of dogs that died does not differ from surviving animals regarding ACTH, basal cortisol, post ACTH-cortisol and $\Delta$-cortisol levels.

On the other hand, animals that survived showed significantly higher increase in cortisol levels after ACTH stimulation ( $\mathrm{p}<0.05$, Wilcoxon), whereas animals that died showed lower increase.

\section{Discussion}

Studies on adrenal function carried out in critically ill dogs include patients with varying conditions of medical and/ or surgical disease. One of the most important limitations is the diversity of diseases and the small number of animals, undermining statistical analysis, as well as the possibility of prior use of glucocorticoids outside the hospital environment, which affects the HPA axis. The same limitations are found in this study, of which results indicate the existence of CIRCI in some of the critically ill patients studied.

Considering this, we observed that stimulation test with synthetic ACTH at low dose (1 ug kg) presented effective in adrenal function assessment in the group of healthy dogs, showing a significant and approximately 5 -fold increase in cortisol values after ACTH stimulation. To evaluate adrenal function in dogs through the stimulation test with synthetic ACTH, the most commonly used protocol on veterinary medicine routine, uses doses as high as 250 ug per dog, or $5 \mathrm{ug} / \mathrm{kg}$, as more recently used.
Moreover, the ACTH stimulation test with low dose has shown to be efficient in stimulating the adrenal gland in critically ill dogs, as demonstrated by the statistical analysis, where cortisol values after stimulation test were significantly higher than basal ones. Previous studies showed that lower doses, such as 0.5 and $1.0 \mathrm{ug} / \mathrm{kg}$ are effective in adrenal function evaluation, allowing an even more appropriate evaluation of the axis, avoiding supraphysiological doses as well as more economical use of synthetic ACTH (Martin et al., 2007). The results obtained in this study corroborate these statements.

However, the absence of a group to assess the HPA axis with the traditional dose of synthetic ACTH still is a limitation, and is suggested for future studies. Regarding the endogenous plasma ACTH values, results obtained in the group of normal dogs are consistent with the literature, which describe variations between 10 and $80 \mathrm{pg} / \mathrm{mL}$ (Prittie et al., 2002). Although the ACTH values in critically ill dogs do not statistically differ from the group of normal dogs, we observed that three animals (two with sepsis and one with pancreatitis) from the group of critically ill dogs showed a decrease in endogenous ACTH, suggesting impaired pituitary response in the presence of stress. This is similar to that reported in previous studies on dogs with sepsis (Martin et al., 2007; Prittie et al., 2002). Seven showed increase from the established normal values, indicating adequate pituitary response to stress.

Regarding the adrenal function assessment, significantly higher basal cortisol levels were found in dogs from the group of critically ill dogs, when compared to healthy ones. Values above the established normal level were observed in nine of the critically ill animals, as mentioned in studies where critical patients respond to stress by increasing basal 
cortisol levels, both in veterinary and human medicine (Hamrahian et al., 2004; Prittie et al., 2002; Schoeman et al., 2007). On the other hand, two dogs (sepsis and DKA) had lower basal cortisol values, demonstrating the inadequacy of the adrenal response, according to the consensus for human patients of the American College of Critical Care Medicine (Marik et al., 2008). However, in critical illnesses, hypoproteinemia is common, especially in cases of sepsis, which occurred in the present study, as of the eight dogs with CIRCI, four animals showed hypoalbuminemia (one DKA and three with sepsis). This event could lead to a decrease in the measurement of total serum cortisol, as more than $90 \%$ of cortisol is carried by plasma proteins (transcortin and albumin), in addition to the fact that, in a critical patient, the percentage of free cortisol increases (Arafah, 2006; Marik et al., 2008; Martin, 2011).

As for cortisol levels after ACTH stimulation, no significant differences were observed between the control and critically ill groups, and no animal showed evidence of primary adrenal insufficiency, as also shown in another study of dogs with sepsis (Burkitt et al., 2007). This statement is based on the fact that, by analyzing the clinical and laboratory variables employed, no dog showed electrolyte or metabolic disorder consistent with primary adrenal insufficiency, such as hyperkalemia, hyponatremia, or severe hypoglycemia.

Also, $\Delta$-cortisol values did not differ between healthy dogs and critically ill ones, but when analyzing individual patient outcomes in light of established normal values, we verified that a significant number of critically ill dogs (37.5\%; one case of pancreatitis, two DKA and three sepsis) showed a weak adrenal response to corticotrophin, characterized by $\Delta$-cortisol levels $<6.3 \mu \mathrm{g} / \mathrm{dL}$, and, in parallel, there was a significant increase from basal to post-ACTH cortisol in dogs that survived. This finding of CIRCI is contrary to that reported in human medical literature (Arafah, 2006; Marik et al., 2008; Moraes et al., 2011). If the analysis of the results used the criteria established by Burkitt et al. (2007), whose $\Delta$ cortisol-value $<3 \mu \mathrm{g} / \mathrm{dL}$ showed higher accuracy in predicting mortality and hypotension, a single dog in this group would exhibit the components for critical illness-related corticosteroid insufficiency. It is noteworthy that this dog died.

Of the assessed critically ill dogs, eight had evidence of CIRCI (decreased values of endogenous ACTH, basal cortisol, or $\Delta$-cortisol). Of these, four had sepsis. The association between sepsis and adrenal dysfunction is very strong, at least in human medical literature, where up to $70 \%$ of patients with sepsis or septic shock can show impairment of the HPA axis, probably associated with excessive release of cytokines and other pro-inflammatory mediators, which would act by suppressing the release of corticotropin-releasing hormone (CRH) and ACTH (Arafah, 2006; Marik et al., 2008; Moraes et al., 2011). In a study of 33 dogs with sepsis carried out by Burkitt et al. (2007), 48\% showed evidence of CIRCI, and $\Delta$-cortisol values $<3 \mu \mathrm{g} / \mathrm{dL}$ were associated with a 4 -fold increase in the chance of death.

\section{Conclusions}

According to the results obtained in this study, we concluded that the stimulation test with synthetic ACTH at low doses $(1 \mathrm{ug} / \mathrm{kg})$ was effective for the evaluation of adrenal function in normal and critically ill dogs. Additionally, partial corticosteroid insufficiency is present in a significant number of critically ill dogs, particularly those with sepsis, suggesting the need for glucocorticoid-based steroid replacement therapy upon hospitalization and therapeutic intervention in these animals. Moreover, studies on adrenal function carried out in critically ill dogs presents as major limitations the diversity of diseases and the small number of selected animals, as well as the possibility of previous use of glucocorticoids, which would affect the HPA axis, impairing data analysis. These same limitations are found in the present study.

\section{Conflict of Interest}

No conflicts.

\section{Ethics Statement}

The study was approved by the Ethics Committee for Animals use of Anhembi Morumbi University (CEUA N. 00720147).

\section{Acknowledgements}

We would like to thank National Council for Scientific and Technological Research and Development (CNPq) for the scholarship that allowed the development of the entire study, to Anhembi Morumbi University Veterinary Hospital and Pompeii Veterinary Hospital, including the entire team of veterinary doctors, for allowing us access to their daily routine and infrastructure for the development and collection of the study data, the entire team of Laboratory of Hormones and Molecular Genetics LIM42/HC-FMUSP, which provided us with the assessment of endogenous ACTH samples, and all the PROVET team - Veterinary Diagnostic Medicine, for providing basal and after ACTH cortisol measurements. 


\section{References}

American Association of Critical-Care Nurses. About critical care nursing [Internet]. Aliso Viejo: AACN; 2012 [cited 2012 Dec 3]. Available from: http://www.aacn.org

Arafah BM. Review: hypothalamic pituitary adrenal function during critical illness: limitations of current assessment methods. J Clin Endocrinol Metab. 2006;91(10):3725-45. http://dx.doi.org/10.1210/jc.2006-0674. PMid:16882746.

Botsford A, Behrend EN, Kemppainen RJ, Gaillard PR, Oprandy F, Lee HP. Low-dose ACTH stimulation testing in dogs suspected of hypoadrenocorticism. J Vet Intern Med. 2018;32(6):1886-90. http://dx.doi.org/10.1111/jvim.15256. PMid:30230611.

Burkitt JM, Haskins SC, Nelson RW, Kass PH. Relative adrenal insufficiency in dogs with sepsis. J Vet Intern Med. 2007;21(2):226-31.https://doi.org/10.1111/j.1939-1676.2007. tb02953.x. PMid:17427381.

Burkitt JM. Controversies surrounding critical illness-related corticosteroid insufficiency in animals. J Vet Emerg Crit Care (San Antonio). 2015;25(1):107-12.

Fede G, Spadaro L, Tomaselli T, Privitera G, Germani G, Tsochatzis E, Thomas M, Bouloux PM, Burroughs AK, Purrello F. Adrenocortical dysfunction in liver disease: a systematic review. Hepatology. 2012;55(4):1282-91. http:// dx.doi.org/10.1002/hep.25573. PMid:22234976.

Hamrahian AH, Oseni TS, Arafah BM. Measurements of serum free cortisol in critically III patients. N Engl J Med. 2004;350(16):1629-38. http://dx.doi.org/10.1056/ NEJMoa020266. PMid:15084695.

Holford AL, Tobias KM, Bartges JW, Johnson BM. Adrenal response to adrenocorticotropic hormone in dogs before and after surgical attenuation of a single congenital portosystemic shunt. J Vet Intern Med. 2008;22(4):832-8. https://doi. org/10.1111/j.1939-1676.2008.0142.x. PMid:18647153.

Lian XJ, Huang DZ, Cao YS, Wei YX, Lian ZZ, Qin TH, He PC, Liu YH, Wang SH. Reevaluating the role of corticosteroids in septic shock: an updated meta-analysis of randomized controlled trials. BioMed Res Int. 2019;2019:3175047. http:// dx.doi.org/10.1155/2019/3175047. PMid:31281831.

Marik PE, Pastores SM, Annane D, Meduri U, Sprung CL, Arlt W, Keh D, Briegel J, Beishuizen A, Dimopoulou L, Tsagarakis S, Singer M, Chrousos GP, Zaloga G, Bokhari F, Vogeser M. Recommendations for the diagnosis and management of corticosteroid insufficiency in critically ill adult patients: consensus statements from an international task force by the American College of Critical Care Medicine. Crit Care Med. 2008;36(6):1937-49. http://dx.doi.org/10.1097/ CCM.0b013e31817603ba. PMid:18496365.
Martin LG, Behrend EN, Mealey KL, Carpenter DM, Hickey KC. Effect of low doses of cosyntropin on serum cortisol concentrations in clinically normal dogs. Am J Vet Res. 2007;68(5):555-60.

Martin LG, Groman RP, Fletcher DJ, Behrend EN, Kemppainen RJ, Moser VR, Hickey KC. Pituitary-adrenal function in dogs with acute critical illness. J Am Vet Med Assoc. 2008;233(1):8795. http://dx.doi.org/10.2460/javma.233.1.87.

Martin LG. Critical illness-related corticosteroid insufficiency in small animals. Vet Clin North Am Small Anim Pract. 2011;4(4):767-82, vi. http://dx.doi.org/10.1016/j.cvsm.2011.03.021. PMid:21757092.

Martins RC, Jericó MM. Uso de baixa dose de ACTH sintético no teste de estimulação da função adrenal para o diagnóstico e controle do hiperadrenocorticismo canino: avaliação da eficácia diagnóstica. Pesq Vet Bras. 2017;37(3):241-7. http:// dx.doi.org/10.1590/s0100-736x2017000300007.

Moraes RB, Czepielewisk MA, Friedman G, Borba EL. Diagnosis of adrenal failure in critically ill patients. Arq Bras Endocrinol Metab. 2011;55(5):295-302. https://doi. org/10.1590/S0004-27302011000500001.

Peyton JL, Burkitt JM. Critical illness- related corticosteroid insufficiency in a dog with septic shock. Journal of Veterinary Emergency and Critical Care Society. 2009:265-8.

Prittie JE, Barton LJ, Peterson ME, Kemppainen RJ, Herr LG, Fox RL. Pituitary ACTH and adrenocortical secretion in critically ill dogs. J Am Vet Med Assoc. 2002;220(5):615-9. http://dx.doi.org/10.2460/javma.2002.220.615.

Salluh JI, Fuks AG. Relative adrenal failure and the use of steroids in sepsis: are we closer to a concensus? Rev Bras Ter Intensiva. 2006;18(1):7-8. https://doi.org/10.1590/S0103507X2006000100002. PMid:25310320.

Schoeman JP, Goddard A, Herrtage ME. Serum cortisol and thyroxine concentrations as predictors of death in critically ill puppies with parvoviral diarrhea. J Am Vet Med Assoc. 2007;231(10);1534-9.

Yao Y, Lin L, Gu H, Wu J, Niu Y, Zhang Z. Are corticosteroids beneficial for sepsis and septic shock? Based on pooling analysis of 16 studies. Front Pharmacol. 2019;10:714. http:// dx.doi.org/10.3389/fphar.2019.00714. PMid:31354473.

Financial Support: This work was supported by Conselho Nacional de Desenvolvimento Científico e Tecnológico $-\mathrm{CNPq}$. 